\title{
Mathematical model of pantograph cooperation with two degrees of freedom with a catenary system
}

\author{
Marek Kaniewski ${ }^{1, *}$, and Michat Cichoński ${ }^{2}$ \\ ${ }^{1}$ Railway Research Institute, Chłopickiego 50, 04-275 Warsaw, Poland \\ ${ }^{2}$ Stemmann-Polska Sp. z o.o.. ul. Spółdzielcza 22, 55-080 Kąty Wrocławskie
}

\begin{abstract}
The authors present a method of modeling pantograph cooperation with a catenary system by means of a computer program based on a pantograph discrete model with two degrees of freedom and a catenary system model as a focused mass that in the dynamic state has variable stiffness along the span. After performing the appropriate tests, the validation was carried out according to the proposed method in the PN EN 50318:2019-02 standard required in the Technical Specifications for the interoperability of the subsystem "Energy" and "Rolling stock - locomotives and passenger rolling stock" of the trans-European rail system in Europe.
\end{abstract}

\section{Introduction}

In the scientific literature, many models are described that allow for more or less accurate description of the interaction of the pantograph with the catenary system. These are models based on solving equations or systems of second order differential equations using analogue computers [3] or digital [5] [7] [8]. To create programs calculating the parameters assessing the quality of cooperation, various computing environments are used, for example MES, MRS, MATLAB \& Simulink [7], Delphi.

In studies [1] [2] [3] [4] [5], the authors describe as one of the possible models describing the cooperation of the pantograph with the overhead contact line, the pantograph model with two degrees of freedom and the overhead contact line represented as a one-dimensional model with clustered parameters at the contact point. The model of the overhead contact line is reduced to one concentrated mass with the stiffness specified in relationship (1) and (2). The pantograph consists of two concentrated masses connected by elastic-damping elements. For the model to be used, for example, in the process of designing the catenary system or checking a new type of pantograph on a new type of rail vehicle, it should be validated according to the requirements of PNEN 50318:2019-02 [6]. The validation process is twostage. First, the simulation result obtained using the mathematical model is compared with the reference results given in the standard [6] and then with the results obtained during the actual journeys on the catenary system. The simulations are carried out at the driving speed of 250 and $300 \mathrm{~km} / \mathrm{h}$ and compared with the reference parameters given in the standard [6].

\section{Description of the model used}

To simulate the quality of the pantograph's cooperation with the catenary system, the model according to [3] was adopted (the model diagram is shown in Figure 1) with the following assumptions:

- the pantograph model has two degrees of freedom taking into account the division of the pantograph into two masses, $\mathrm{m} 1$ and $\mathrm{m} 2$,

- the mass of the catenary system represented by substitute mass is focused at the contact point, it is constant at the length of the span, this assumption is also given by the source [1],

- the frequency of natural vibrations of the overhead contact line is constant along the span,

- the stiffness of the overhead contact line changes sinusoidally along the span and has the minimum in the middle of the span and the maximum for the support structure,

- dry and sticky friction in the overhead contact line is omitted,

- the mass of the pantograph is reduced to the point of contact with the contact wire and fixed regardless of the height relative to the roof of the electric head,

- there is dry friction in the pantograph and shoe arms by a value of $-w_{0}$ or $+w_{0}$ in the opposite direction than the movement; changes in steps according to the signum function,

- sticky friction is taken into account by the proportionality factor to the speed of movement of the contact point and its value is reduced to the point of contact,

- the static force exerted by the pantograph drive system is constant for each electric head movement speed and the position of the pantograph, 
- the vertical component of the aerodynamic drag force is always positive (directed upwards) and proportional to the square of the speed of movement of the rail vehicle,

- the influence of the locomotive vibrations was omitted,

- the movement starts in the middle of the span and takes place at a constant speed.

The stiffness of the overhead contact line is described by dependence (1).

$$
k_{s}=k_{s 1}-k_{s 2} * \cos \Omega(t)
$$

where: $k_{\mathrm{s} 1}$ - average value of overhead contact line stiffness in $\mathrm{N} / \mathrm{m}$,

$k_{\mathrm{s} 2}$ - amplitude of the overhead contact line stiffness in $\mathrm{N} / \mathrm{m}$,

$\Omega$ - pantograph travel frequency under supporting structures in rad/s according to relationship (2),

$$
\Omega=\frac{2 \pi v}{L},
$$

where: $v$ - displacement speed of the pantograph mounted on the rail vehicle

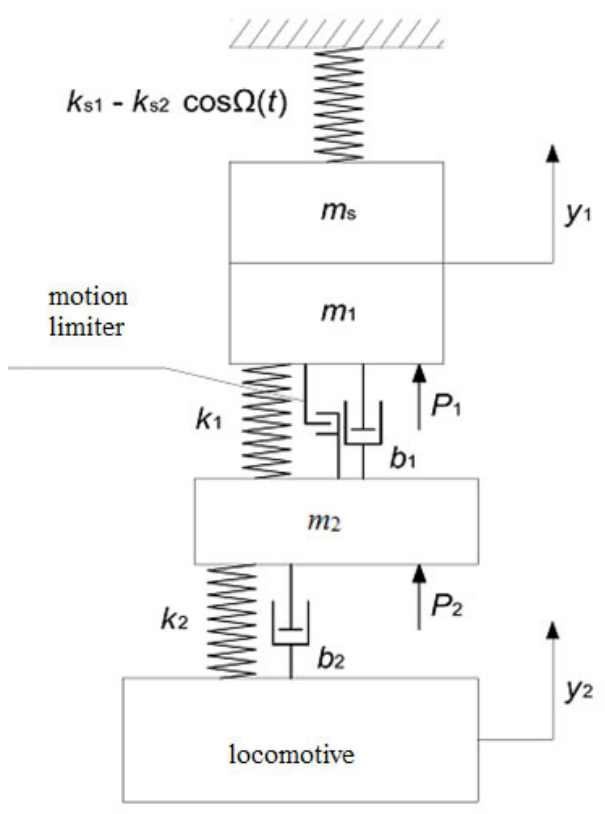

Fig. 1. The pantograph model of a two degrees of freedom. Source [3]

For the above-described assumptions, a system of equations describing the traffic equation according to [3] was written on the basis of the dynamic equilibrium of reduced masses to overhead contact line and pantograph in accordance with the principle of d'Alembert.

$$
\begin{aligned}
& \left(m_{s}+m_{s 1}\right) \ddot{y_{1}}+b_{1}\left(\dot{y_{1}}-\dot{y}_{2}\right)+ \\
& +k_{1}\left(y_{1}-y_{2}\right)+\left(k_{s 1}-k_{s 2} \cos \Omega t\right) y_{1}=P_{1}, \\
& m_{2} \ddot{y}_{2}+b_{1}\left(\dot{y}_{2}-\dot{y}_{1}\right)+k_{1}\left(y_{2}-y_{1}\right)+b_{2} \dot{y}=P_{2},
\end{aligned}
$$

where: $m_{1}$ - the mass of the pantograph head,

- $m_{2}$ - pantograph's shoulder mass reduced to the contact point,

- $\quad k_{1}$ - stiffness of the electric head 's suspension,

- $\quad b_{1}$ - damping coefficient of viscous displacement of the electric head,

- $b_{2}$ - damping coefficient of viscous pantograph arm displacement,

- $\quad y_{1}$ - displacement of the contact point of the electric head with the contact wire,

- $y_{2}$ - vertical displacement of the contact of the upper pantograph arm node,

- $P_{1}$ - aerodynamic force acting on the electric head,

- $P_{2}$ - the sum of aerodynamic forces acting on the pantograph arms and the static force generated by the propulsion system.

For the validation process, the following value required by the standard [6] was adopted: $P_{l}=0 \mathrm{~N}$, $P_{2}=120 \mathrm{~N}, m_{1}=7.2 \mathrm{~kg}, m_{z}=15 \mathrm{~kg}, k_{1}=4200 \mathrm{~N} / \mathrm{m}, k_{2}=50$ $\mathrm{N} / \mathrm{m}, b_{1}=10 \mathrm{Ns} / \mathrm{m}, b_{2}=90 \mathrm{Ns} / \mathrm{m}$; the overhead contact line, which has one contact wire with a unit mass of 1.07 $\mathrm{kg} / \mathrm{m}$ and one supporting rope with a unit mass of 1.35 $\mathrm{kg} / \mathrm{m}$; consisting of 10 identical spans with a length of 60 $\mathrm{m}$; the stagger of contact wire's is $0.2 \mathrm{~m}$; the pulls are respectively the contact wire $-20000 \mathrm{~N}$ and the carrier rope $16000 \mathrm{~N}$; aerodynamic force equal to 0 . Adopted driving speed during $250 \mathrm{~km} / \mathrm{h}$ simulation. The vibration damping for the contact wire is $0 \mathrm{Ns} / \mathrm{m}$. The overhang of the contact wire is also 0. During the simulation, the overhead contact line cooperates with one pantograph. The parameters calculated for the spans 5 and 6 are analyzed - in the middle of the stress section where the lowest values of forces extending the contact wire and the supporting rope should be expected. The spacing of hangers was given in the standard [6].

\section{Simulation results}

The calculations of contact forces in the simulation process occurring between the reference pantograph and the reference overhead contact line were made using a computer program created using the Delphi 10.2 Professional package. The following parameters are loaded during the program startup: static pantograph force, as a mean constant value for the pantograph operating range, dry and viscous damping of the first and second pantograph spring, mass of the shoe and the mass of the articulated frame (arms), springing force of the electric head, springs' spacing, maximum deflection of the electric head's springs, length of the overhead contact line span, distance of the contact wire from the track axis, average value and amplitude of the overhead contact line rigidity, frequency of overhead contact line oscillation, reduced net mass in the half of the span and under the column, four factors concerning aerodynamic impact, vehicle movement speed the same as the 
pantograph, the vibration frequency of the rail vehicle, the amplitude of the locomotive's springing. Some values have assumed zero values (they are given in p.2). An analysis was carried out confirming the validation of the adopted method and additionally 5 calculation variants showing the possibilities of the program. The validation of the calculation method is shown in Figures 2 and 3. Fig. 2 shows the diagram of the contact force between the pantograph head and the contact wire of the overhead contact line obtained as a result of simulation for the reference model. The length of the simulated section corresponds to the length of 10 spans of the reference overhead contact line. The simulation discretization was $0.02 \mathrm{~s}$. Therefore the frequency of the next calculated points is $50 \mathrm{~Hz}$.

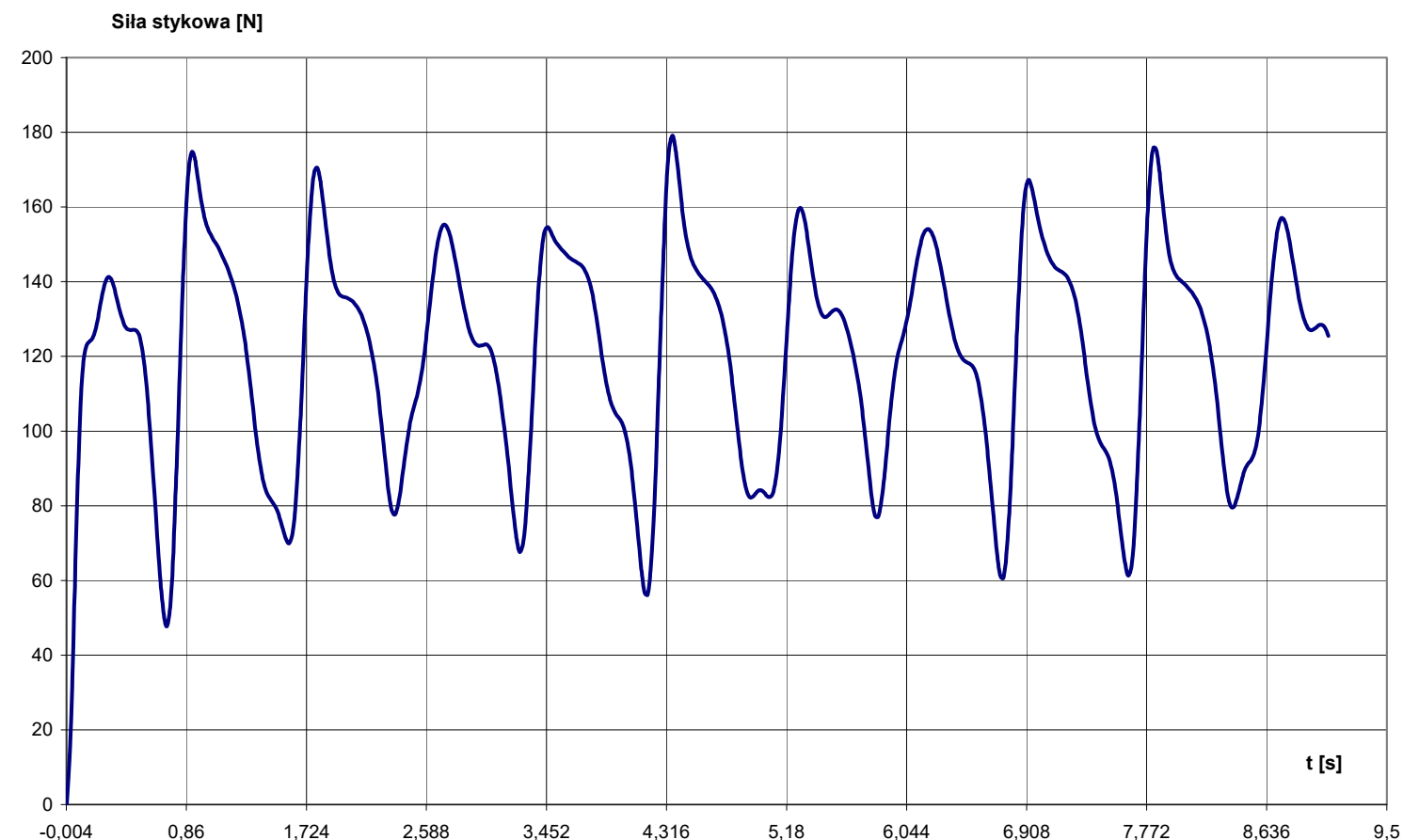

Fig. 2. The simulation result of the contact force for 10 spheres of the reference and reference pantograph, speed $250 \mathrm{~km} / \mathrm{h}$

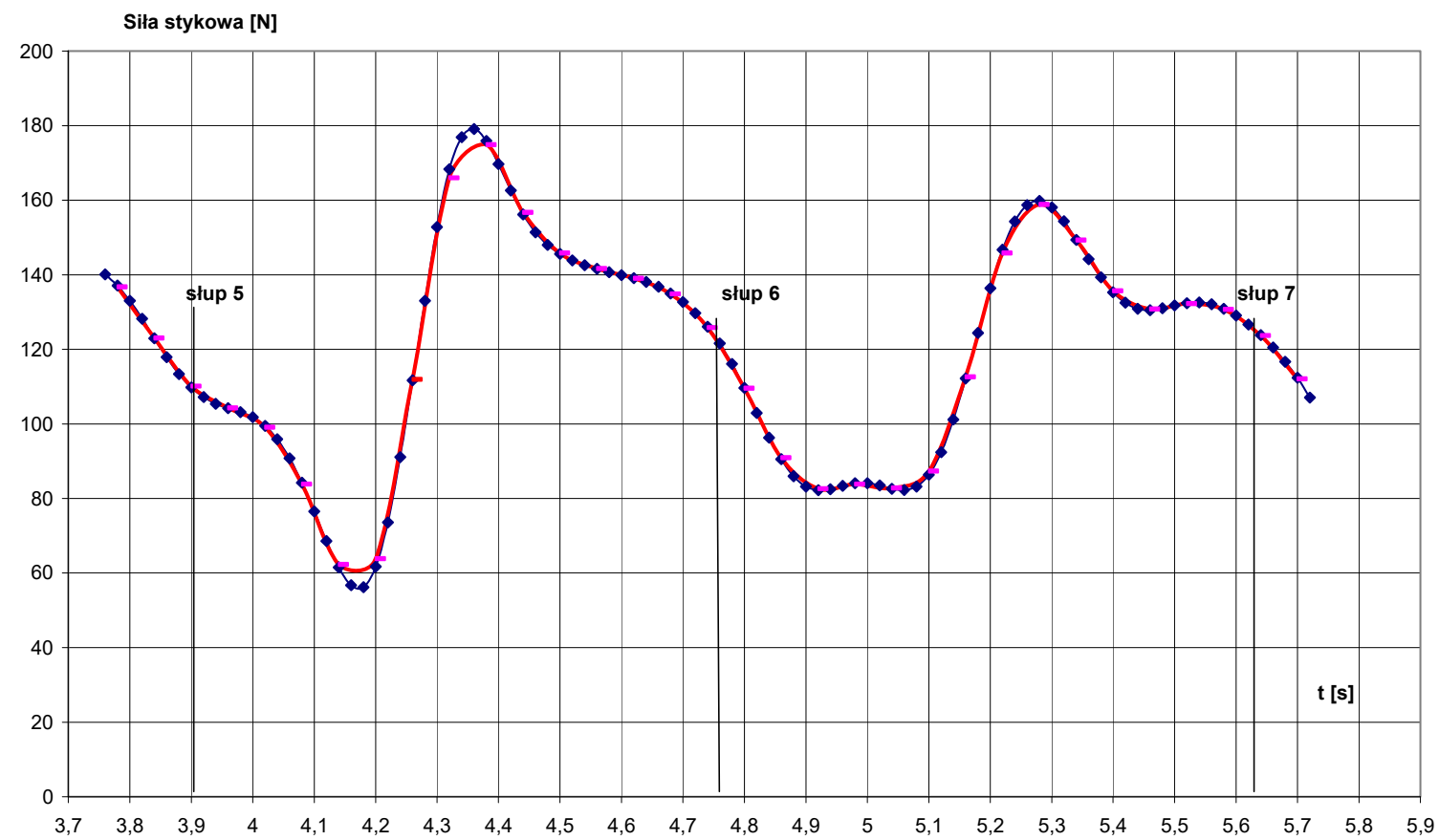

Fig. 3. Simulation result for 5 and 6 spans of contact force for the speed of eating $250 \mathrm{~km} / \mathrm{h}$ (blue line frequency $50 \mathrm{~Hz}$, red line 20 $\mathrm{Hz})$ 
Figure 3 shows the course of the contact force for the preferred by the standard [6] bays 5th and 6th. The thin blue line shows the course for the frequency of calculation $50 \mathrm{~Hz}$ and the thick red line for the frequency $17 \mathrm{~Hz}$ (frequency $20 \mathrm{~Hz}$ in this case can not be obtained). Point $3 \mathrm{~A}$ of the standard [6] requires that the results be filtered with a low-pass filter from 0 to $20 \mathrm{~Hz}$. Practically speaking, there are no fundamental differences between the course obtained in the simulation process and filtered in the range from 0 to 20 $\mathrm{Hz}$.

Using the program, you can analyze the value of the contact force for the changed important parameters, for example the pantograph. Thus, changing the reduced mass of the electric head to $20 \mathrm{~kg}$ and the reduced mass of the pantograph arms to $30 \mathrm{~kg}$, we get the course shown in Fig. 4. For this course, the mean value of the FM contact force has risen slightly and amounts to 121 $\mathrm{N}$, the standard deviation is $69 \mathrm{~N}$, so it has increased over $100 \%$ a minimum momentary contact force decreased to $2 \mathrm{~N}$. Such parameters do not meet the criteria of proper cooperation of the pantograph with the overhead contact line. The contact force with a $2 \mathrm{~N}$ value will cause a spark between the pantograph electric head and the contact wire.

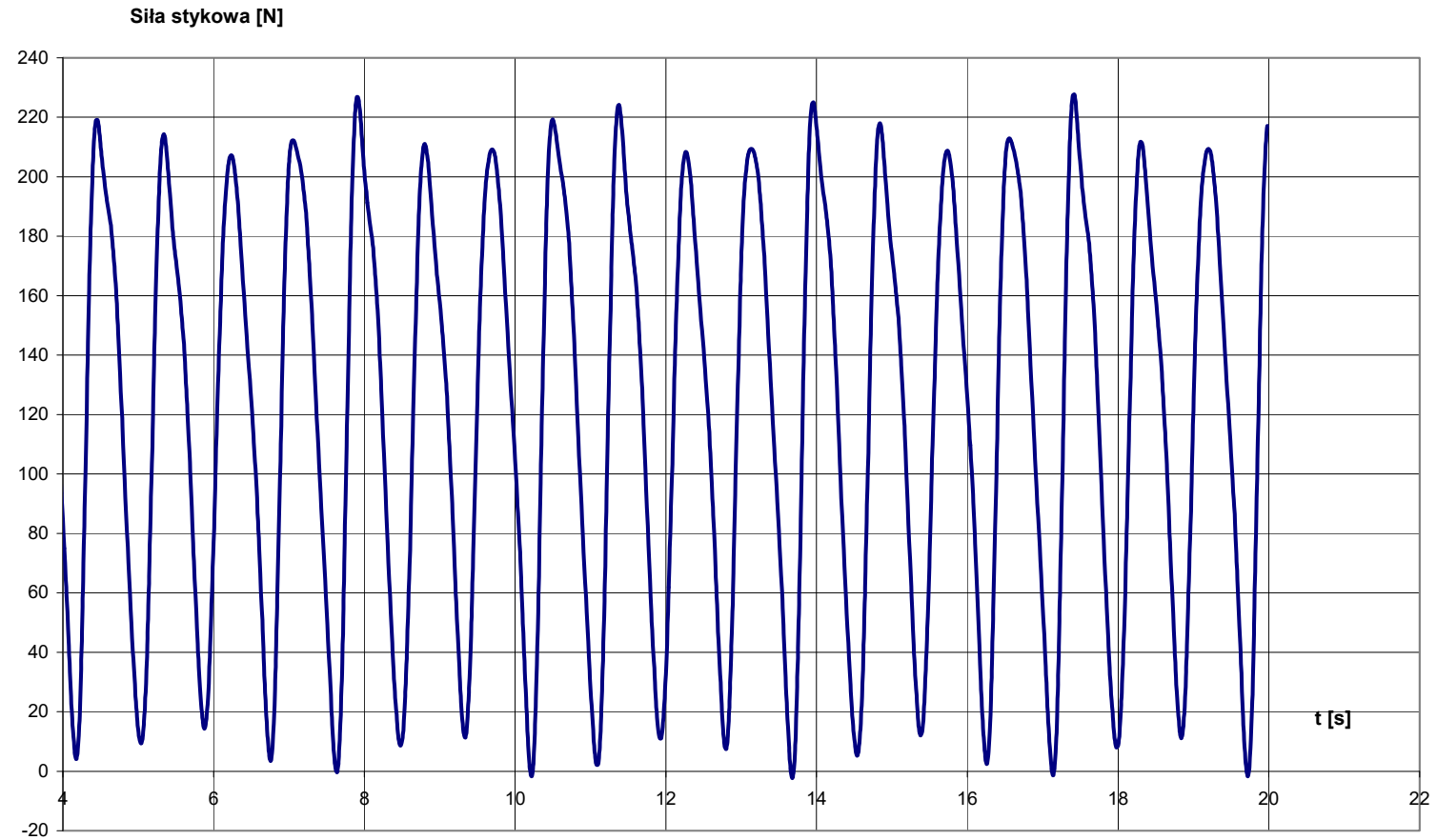

Fig. 4. Simulation result for the reference catenary system and pantograph with a reduced mass of $20 \mathrm{~kg}$ and a reduced pantograph arm mass of $30 \mathrm{~kg}$, speed $250 \mathrm{~km} / \mathrm{h}$

The filtering procedure allows for the removal of accidental noise in the waveforms while emphasizing the most important characteristic frequencies occurring in the pantograph - catenary system. The basic frequency of system vibrations results from the length of the spans and the speed of travel. It also depends on the type of catenary system and ranges from 0.7 to $2 \mathrm{~Hz}$. However, the vibration resulting from the distance between hangers at a speed of $250 \mathrm{~km} / \mathrm{h}$ is up to $12 \mathrm{~Hz}$ with the distance between consecutive hangers $6 \mathrm{~m}$.

The obtained results from stimulation were compared with the values given in the standard [6]. The speed during the simulation was $250 \mathrm{~km} / \mathrm{h}$.

In the next case under consideration (Fig. 5), the static force value changed to $90 \mathrm{~N}$ in the data. After the calculation, the average contact force was $90 \mathrm{~N}$, the standard deviation of the contact force was $23 \mathrm{~N}$, the maximum force value was $141 \mathrm{~N}$ and the minimum value of the contact force was $35 \mathrm{~N}$. Such quality parameters of the pantograph's cooperation with the overhead contact line should be considered correct.
There will be no sparking between the contact wire and the pantograph electric head. The contact wire will wear to a minimum.

We will also disagree with the case in which there was a significant increase in the dry friction force in the electric head's suspension (obliteration in the electric head or chafing caused by a collision with the catenary system elements). Let us assume then that the dry friction force of one side of the electric head is $190 \mathrm{~N}$. After the calculation, the average contact force was 119 $\mathrm{N}$, the standard deviation of the contact force is $48 \mathrm{~N}$, the maximum value of the contact force $288 \mathrm{~N}$ and the minimum contact force $21 \mathrm{~N}$. The calculated quality parameters of cooperation pantograph with overhead contact line proves that the contact between the contact wire and the electric head is incorrect.

The following phenomena will occur in the contact between the contact wire and the electric head cover: contact breaks, possibly overburning one conductor, faster contact wire wear. The course of contact forces in this case is shown in Figure 6. 


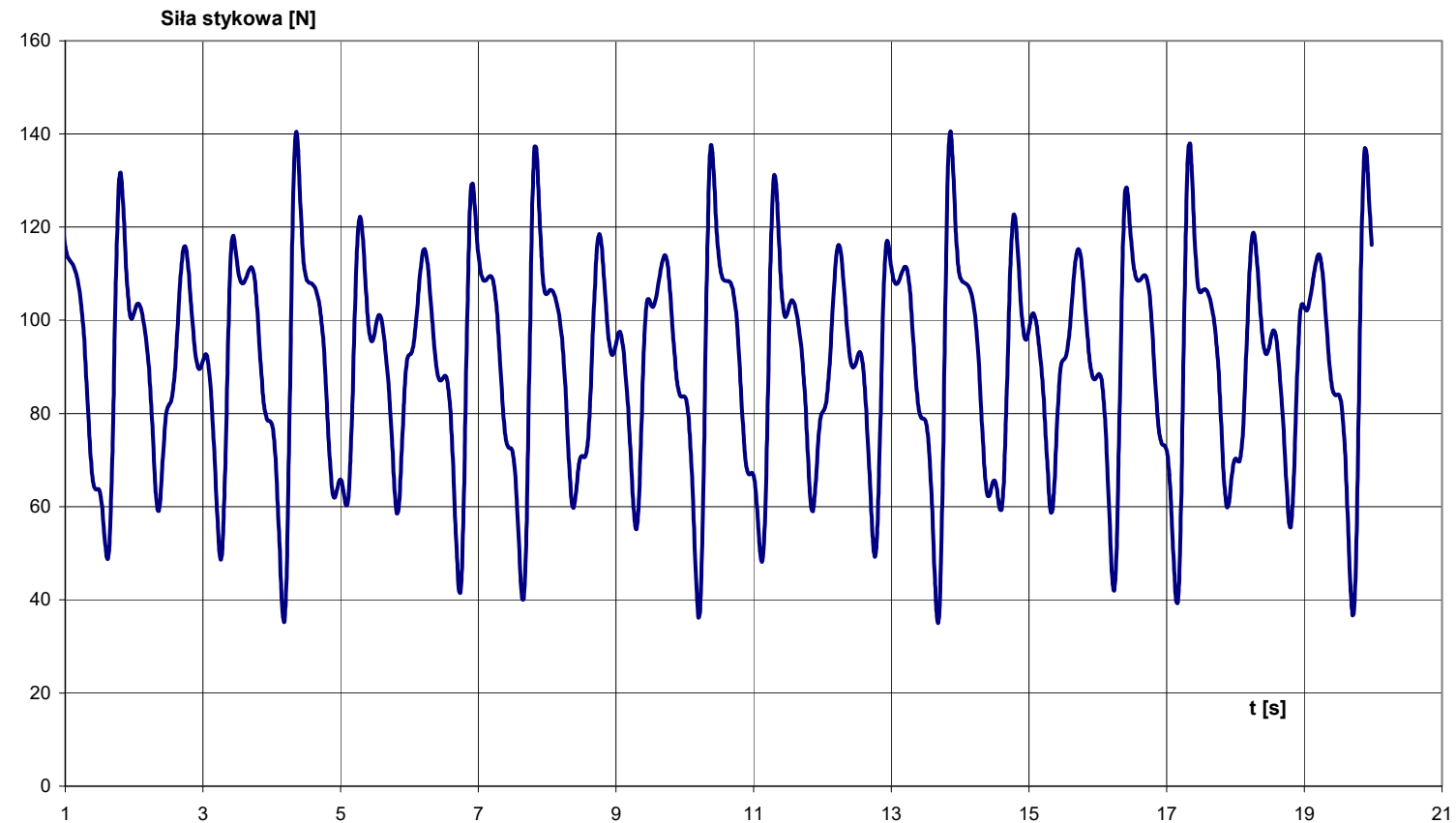

Fig. 5. Simulation result for reference catenary system and pantograph when static force $F=90 \mathrm{~N}$, speed $250 \mathrm{~km} / \mathrm{h}$

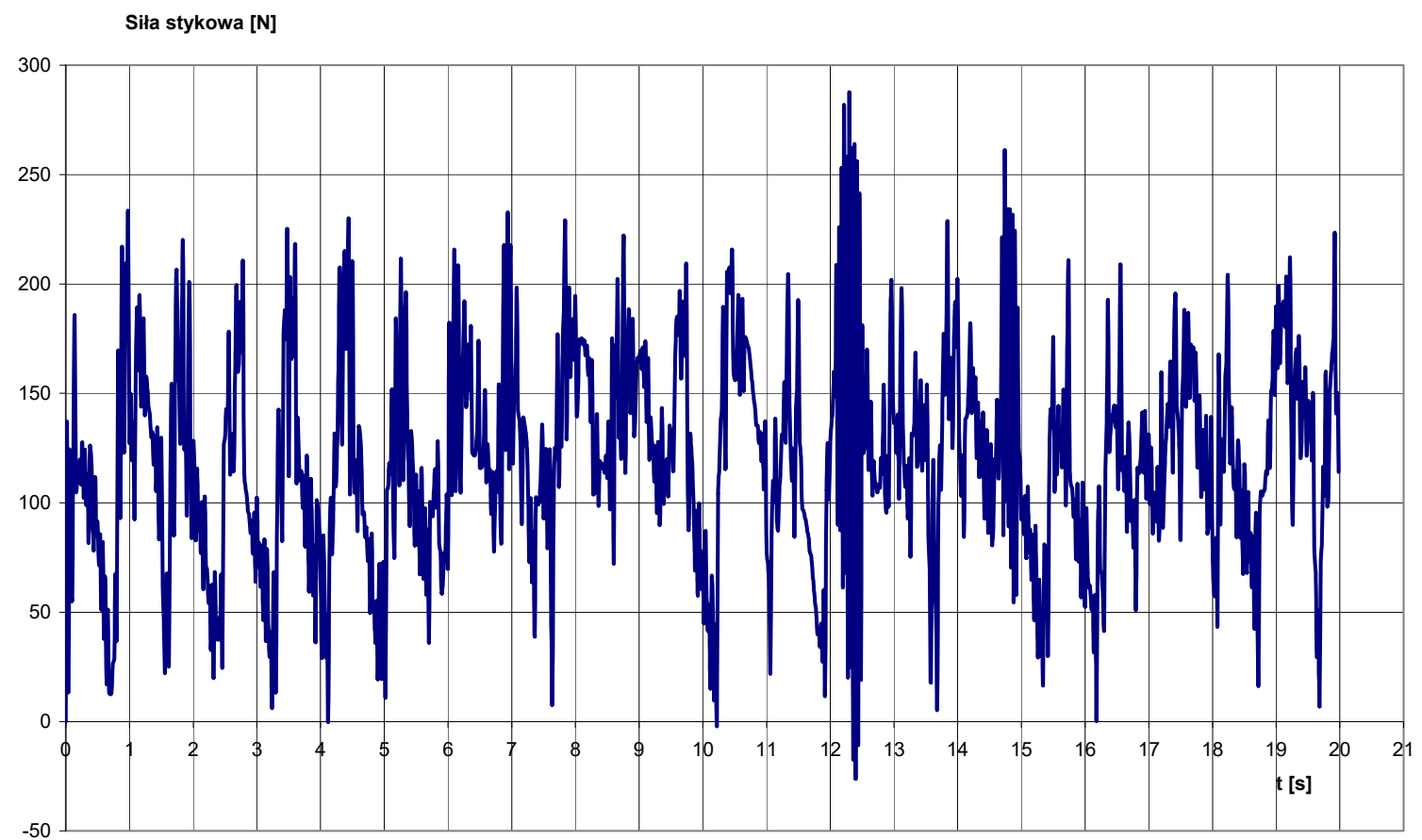

Fig. 6. Simulation result for reference catenary system and pantograph contact force $F=90 \mathrm{~N}$, travelling speed $250 \mathrm{~km} / \mathrm{h}$

In the next case under consideration, we assume that the pantograph's universal joint has become seized. The calculation of the force of such an event is shown in Figure 7. It is a simulation diagram of the reference catenary system and pantograph in which the stiffness of the electric head was changed 1.6 times compared to the reference pantograph. The following values of the rated parameters were obtained: the average value of the contact force was $120 \mathrm{~N}$, the standard deviation of the contact force is $29 \mathrm{~N}$, the maximum value of the force $173 \mathrm{~N}$ and the minimum contact force $57 \mathrm{~N}$. The calculated parameters of the pantograph's cooperation with the catenary system show that between the contact wire and the electric head cooperation, despite increasing the rigidity of the electric head is correct

The next considered case in which there was a significant increase in the dry friction force is the increase of the friction force in the bearings of the 
articulated frame (seizing the bearings). Suppose that then the dry friction force is 10 times greater. After the calculation, the average contact force was $124 \mathrm{~N}$, the standard deviation of the contact force is $40 \mathrm{~N}$, the maximum value of the contact force is $200 \mathrm{~N}$ and the minimum contact force is $4 \mathrm{~N}$. The calculated quality parameters of pantograph cooperation with the catenary system show that between the contact wire and the electric head the cooperation is incorrect. There will be cracks and contact gaps. The instantaneous value of the minimum contact force of $4 \mathrm{~N}$ and the minimum statistical value of $5 \mathrm{~N}$ is unacceptable from the point of view of correct cooperation of the pantograph with the catenary system. The course of contact forces in time for this case is shown in Figure 8.

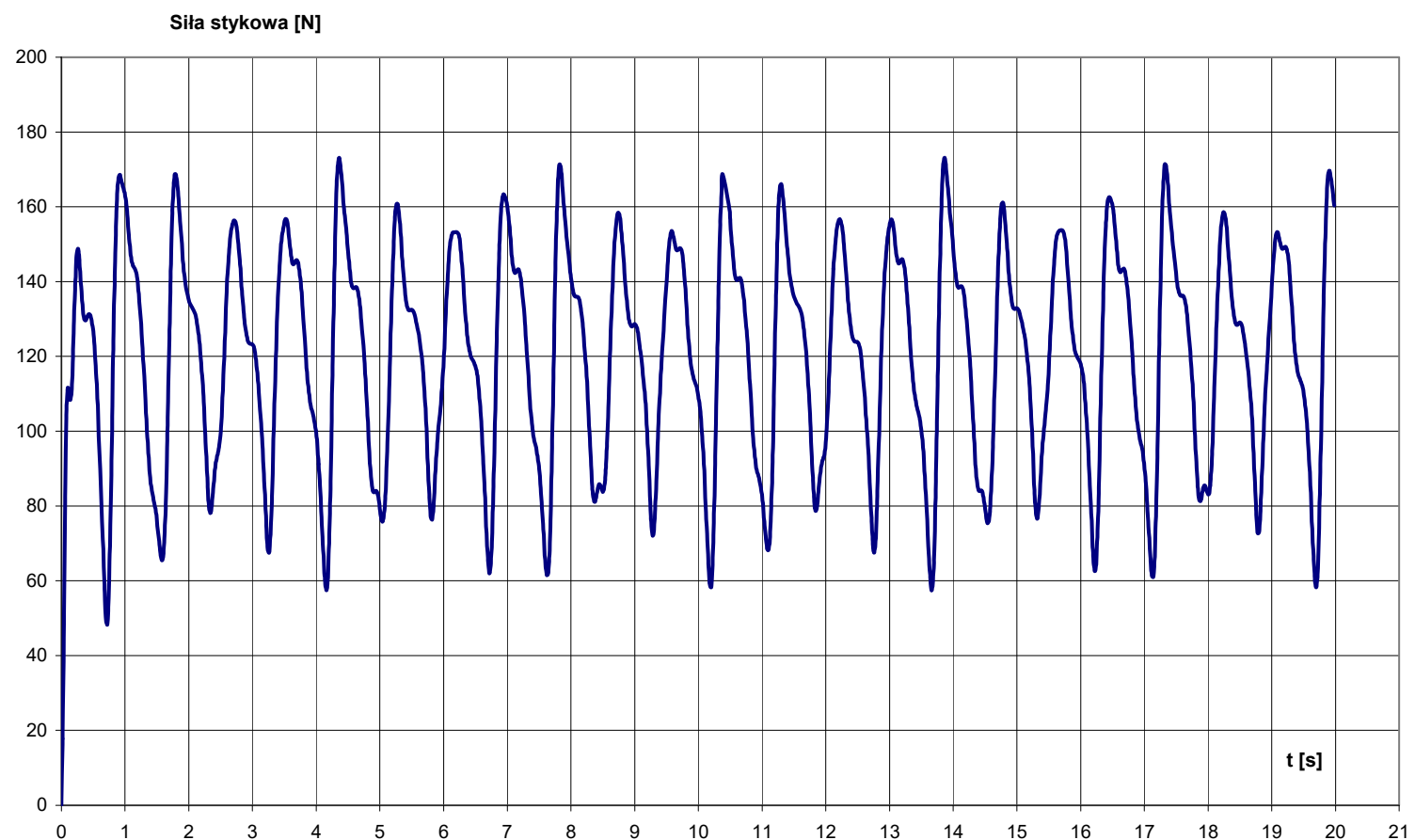

Fig. 7. Simulation result for reference catenary system and pantograph. The stiffness of the electric head has been increased 1.6 times, speed $250 \mathrm{~km} / \mathrm{h}$

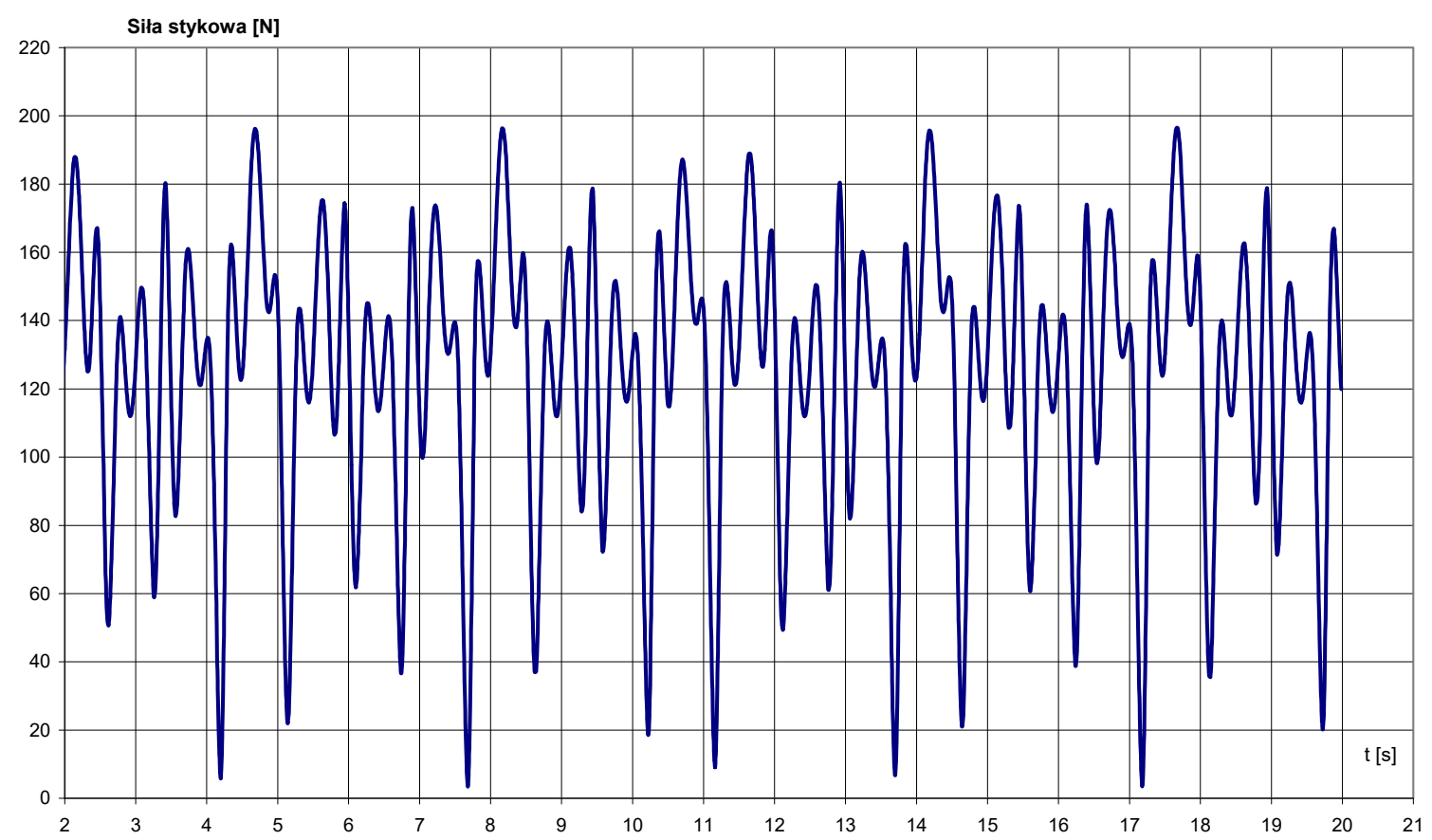

Fig. 8. Simulation result for reference catenary system and pantograph. In the pantograph, the rigidity of the frame has been increased by 10 times, speed $250 \mathrm{~km} / \mathrm{h}$ 
The comparison of simulation results is presented in the table 1 shows the correctness of the dynamics of the simulated system and thus the correctness of the simulation method used.

Table 1. Results of simulation analysis of pantograph cooperation - overhead contact line

\begin{tabular}{|c|c|c|}
\hline Parameters & $\begin{array}{l}\text { Required } \\
\text { range }\end{array}$ & $\begin{array}{l}\text { Simulation } \\
\text { results }\end{array}$ \\
\hline Speed $[\mathrm{km} / \mathrm{h}]$ & \multicolumn{2}{|c|}{250} \\
\hline Obtained results & $\begin{array}{l}\text { According } \\
\text { to the } \\
\text { standard }[6]\end{array}$ & $\begin{array}{l}\text { According } \\
\text { to the } \\
\text { simulation }\end{array}$ \\
\hline $\begin{array}{l}\text { Average contact } \\
\text { force } F_{M}[N]\end{array}$ & $\begin{array}{l}\text { from } 110 \\
\text { to } 120\end{array}$ & 119 \\
\hline $\begin{array}{c}\text { Standard } \\
\text { deviation of the } \\
\text { contact force } \sigma[\mathrm{N}]\end{array}$ & $\begin{array}{l}\text { from } 26 \text { to } \\
\quad 31\end{array}$ & 31 \\
\hline $\begin{array}{c}\text { Statistical } \\
\text { maximum contact } \\
\text { force } \mathrm{F}_{\mathrm{M}}+3 \sigma\end{array}$ & $\begin{array}{l}\text { from } 190 \\
\text { to } 210^{1}\end{array}$ & 212 \\
\hline $\begin{array}{c}\text { Statistical } \\
\text { minimum contact } \\
\text { force } \mathrm{F}_{\mathrm{M}^{-}}-3 \sigma \\
\end{array}$ & $\begin{array}{l}\text { from } 20 \\
\text { do } 40\end{array}$ & 26 \\
\hline $\begin{array}{l}\text { Actual maximum } \\
\text { of the contact force } \\
{[\mathrm{N}]}\end{array}$ & $\begin{array}{l}\text { from } 175 \\
\text { to } 210\end{array}$ & 175 \\
\hline $\begin{array}{l}\text { Actual minimum } \\
\text { of the contact force } \\
{[\mathrm{N}]}\end{array}$ & $\begin{array}{l}\text { from } 50 \text { to } \\
\quad 75\end{array}$ & 62 \\
\hline $\begin{array}{l}\text { Maximum uplift } \\
\text { at support [mm] }\end{array}$ & $\begin{array}{l}\text { from } 48 \text { to } \\
\quad 55\end{array}$ & $\begin{aligned} \mathrm{U}_{5} & =48, \\
\mathrm{U}_{6} & =52 \\
\mathrm{U}_{7} & =54\end{aligned}$ \\
\hline $\begin{array}{c}\text { Percentage of } \\
\text { losing contact }[\%]\end{array}$ & 0 & 0 \\
\hline
\end{tabular}

\section{Summary}

The authors of the article presented a computer program (tool) with the help of which it is possible to make simulations allowing for the analysis of the pantograph's cooperation with the catenary system. Performed simulations with the data given by the standard confirmed that the obtained results for the speed of 250 $\mathrm{km} / \mathrm{h}$ of the reference pantograph with the reference catenary system are in accordance with the requirements of PN-EN 50318:2019-02 [6] and therefore the method described should be considered validated. With the help of this computer program it is possible to analyze the quality of cooperation for different types of pantographs differing in parameters: stiffness of the springs used in the electric head suspension, dry or viscous friction, concentrated mass, static force setting, different aerodynamic conditions, travelling speed (up to 250 $\mathrm{km} / \mathrm{h}$ ). The analysis can also be subject to variable

\footnotetext{
${ }^{1}$ Accepting the limits of the average contact force $120 \mathrm{~N}$ and the deviation of the standard contact force $31 \mathrm{~N}$, the maximum statistical contact force calculated from the relationship $\mathrm{FM}+3 \sigma=120+(3 * 31)=213 \mathrm{~N}$
}

parameters of catenary system: that is, tensile forces, the traction cable, length of the overhead contact line span, distance of the contact wire, maximum and minimum stiffness of the overhead contact line, maximum and minimum mass of the reduced overhead contact line, aerodynamic forces, and speed of travel.

Using the model, you can analyze changes in contact force over time, displacement of the contact point, displacement, velocity and acceleration of the first and second stage of pantograph suspension.

\section{References}

1. Vologin V.A. Interaction between pantograph and contact line, VNIIZhT, Moscow (2006): (rus)

2. Grajnert J.: Nowoczesne rozwiazania konstrukcyjne odbieraków pradu. Trakcja i Wagony nr 5 (1978)

3. Grajnert J.; Wpływ niektórych parametrów odbieraka pradu na siłe stykowa, Pojazdy szynowe nr 4 s. 7 - 13 (1978)

4. Kaniewski M.: Model matematyczny odbieraka pradu i sieci jezdnej. Prace Naukowe Politechniki Warszawskiej Transport z. 95, s. 209-220 (2013).

5. Kobielski A.: Dobór parametrów odbieraka prądu za pomoca systemu komputerowego. Trakcja i Wagony nr 2 (1985)

6. PN-EN 50318:2019-02 - wersja angielska Zastosowania kolejowe. Systemy odbioru pradu. Walidacja symulacji oddziaływania dynamicznego pomiędzy pantografem a siecia jezdna górna.

7. Zdziebki P., Martowicz D., Uhl T.: Modelowanie hybrydowe do symulacji interakcji pantograf i sieć trakcyjnej.

8. Thomas Reichmann, Simulation des Systems Oberleitungskettenwerk und Stromabnehmer mit der Finite-Elemente-Methode. Elektrische Bahnen 103, 1-2. s. 69-75.

9. Rojek A.: Short Circuit Current Breaking by High Seed Circuit Breakers in Traction Substatin. Problemy Kolejnictwa, 177, s. 51-59.

10. Głowacz M., Kaniewski M., Rojek A.: Overhead contact line systems for high-speed rails. Highspeed rail in Poland. Advances and Perspectives. CRC Press/Taylor \& Francis Group. ISBN 978-1138-54469-7, str. 279-300 (2018) 